University of Nebraska - Lincoln

DigitalCommons@University of Nebraska - Lincoln

2016

\title{
Visual Soil Structure Effects of Tillage and Corn Stover Harvest in lowa
}

Cássio A. Tormena

State University of Maringá

Douglas Karlen

USDA-ARS, doug.karlen@ars.usda.gov

Sally D. Logsdon

USDA-ARS, sally.logsdon@ars.usda.gov

Maurício R. Cherubin

University of São Paulo, cherubin@usp.br

Follow this and additional works at: https://digitalcommons.unl.edu/usdaarsfacpub

Tormena, Cássio A.; Karlen, Douglas; Logsdon, Sally D.; and Cherubin, Maurício R., "Visual Soil Structure Effects of Tillage and Corn Stover Harvest in lowa" (2016). Publications from USDA-ARS / UNL Faculty. 1634.

https://digitalcommons.unl.edu/usdaarsfacpub/1634

This Article is brought to you for free and open access by the U.S. Department of Agriculture: Agricultural Research Service, Lincoln, Nebraska at DigitalCommons@University of Nebraska - Lincoln. It has been accepted for inclusion in Publications from USDA-ARS / UNL Faculty by an authorized administrator of DigitalCommons@University of Nebraska - Lincoln. 


\section{Visual Soil Structure Effects of Tillage and Corn Stover Harvest in lowa}

\section{Cassio A. Tormena* \\ State Univ. of Maringá \\ 5790 Colombo Ave. \\ Maringá \\ PR 87020-900 \\ Brazil}

\section{Douglas L. Karlen}

Sally Logsdon

USDA/Agricultural Research Service

National Laboratory for Agric. and the Environ.

2110 University Blvd.

Ames, IA 50011-3120

\section{Maurício R. Cherubin}

Univ. of São Paulo,

"Luiz de Queiroz" College of Agriculture

11 Pádua Dias Ave.

Piracicaba, SP 13418-900

Brazil

\section{Core Ideas}

- VESS detected soil structural quality changes under corn stover harvest and tillage systems.

- A high level of corn stover harvest had an adverse effect on the soil structural quality.

- Under high stover harvest, structural quality in chisel plow was worse than in no-tillage.

- VESS should be further evaluated as an integrative soil quality/health indicator.
High levels of corn (Zea mays L.) stover harvest for ethanol production have raised concerns regarding negative consequences on soil structure and physical quality. Visual soil structure assessment methods have the potential to help address these concerns through simple, straightforward on-farm evaluations. Our objective was to determine if the visual evaluation of soil structure (VESS) approach could detect soil structural quality differences associated with different levels of corn stover harvest and tillage practices. We evaluated no harvest and moderate and high stover harvest levels within no-tillage (NT) and chisel plow (CP) plots following $7 \mathrm{yr}$ of continuous corn. Undisturbed 10- by 20- by 25-cm soil samples were taken using a spade in April 2015. The thickness and structural quality $(\mathrm{Sq})$ scores for the 0- to 5- (top) and 5- to $20-\mathrm{cm}$ (bottom) soil layers were determined, and an overall Sq was computed. The $\mathrm{Sq}$ values showed a significant interaction between corn stover harvest and tillage practice. Soil structural quality showed no significant differences between NT and CP systems for either the no- or moderate-harvest treatments, but with a high stover harvest rate, $C P$ structural quality was worse than NT. With NT, both moderate and high rates of stover harvest significantly increased $\mathrm{Sq}$ compared to no harvest; in $\mathrm{CP}$, there was no significant difference between the no- and moderate-harvest treatments. Only a high level of stover harvest had an adverse effect on the Sq rating. The VESS approach was sensitive for detecting the effects of corn stover harvest and tillage systems on soil structural quality and should be further evaluated as an integrative, on-farm soil quality/health indicator.

Abbreviations: $\mathrm{CP}$, chisel plow; NT, no-tillage; Sq, structural quality; VESS, visual evaluation of soil structure.

A $s$ the demand for ethanol and other renewable biofuels increases, cellulosic conversion facilities (biorefineries) will require increasing amounts of biomass. Corn stover is considered a potential feedstock for secondgeneration ethanol production because of its high cellulosic content, high volume of production, and availability (Karlen et al., 2014) throughout the Midwestern United States. Judicious corn stover harvest for ethanol production and other uses is required to prevent soil erosion, preserve soil organic matter, and maintain high levels of productivity (Wilhelm et al., 2004). Possible soil organic C (SOC) depletion associated with corn stover harvest (Karlen et al., 2011b; Laird and Chang, 2013; Villamil and Nafziger, 2015) could negatively affect soil structure (Six et al., 2000; Osborne et al., 2014) and several soil physical properties and processes related to soil water, $\mathrm{O}_{2}$ and $\mathrm{CO}_{2}$ dynamics, and root growth that are crucial for sustained soil and crop productivity. The impacts of corn stover harvest on soil structural and physical quality have received more attention in recent years, but the specific effects are still not well understood and should therefore be regularly quantified and/or monitored to ensure corn stover harvest strategies are sustainable.

The U.S. Department of Agriculture (USDA) prohibits discrimination in all of its programs and activities. USDA is an equal opportunity provider and employer.

Soil Sci. Soc. Am. J. 80:720-726

doi:10.2136/sssaj2015.12.0425

Received 7 Dec. 2015

Accepted 20 Feb. 2016

*Corresponding author (cassiotormena@gmail.com).

(c) Soil Science Society of America, 5585 Guilford Rd., Madison WI 53711 USA. All Rights reserved. 
Corn stover influences several critical agronomic and environmental functions in Midwestern cropping systems (Wilhelm et al., 2004; Johnson et al., 2006; Blanco-Canqui and Lal, 2009a). Several studies have shown that stover harvest can have negative impacts on near-surface soil structure and physical properties (Blanco-Canqui and Lal, 2008, 2009b; Osborne et al., 2014; Jin et al., 2015). The impacts of stover harvest have generally been assessed through classical soil physical measurements, such as soil bulk density, penetration resistance, aggregate stability, percentage macroaggregation, aggregate tensile strength, infiltration, hydraulic conductivity, air permeability, and soil water retention (Karlen et al., 1994; Blanco-Canqui et al., 2006, 2007, 2014; Blanco-Canqui and Lal, 2007, 2008, 2009b; Moebius-Clune et al., 2008; Kenney et al., 2015; Villamil et al., 2015; Wegner et al., 2015). Those soil properties were chosen because of their indirect relationship to soil structure, but they require substantial methodological expertise and demand tedious sampling and sophisticated laboratory analyses (Guimarães et al., 2013). In several countries around the world, visual soil assessment methodologies have been developed to directly and accurately evaluate soil structural quality.

One example is the VESS method, which was developed by Ball et al. (2007) and improved by Guimarães et al. (2011) to provide a semiquantitative, quick, very practical, accurate but easy to do and understand on-farm method for evaluating and monitoring the impacts of management on soil structural quality. Visual evaluation of soil structure integrates soil properties related to size, shape, strength, and porosity of aggregates and roots into a single number-the Sq score. Structural quality scores range from 1 (good structural quality) to 5 (poor structural quality), with a Sq of 3 being defined as the limit between good and poor soil structural quality (Ball et al., 2007). The VESS has been used for the assessment of soil structural quality in different soils and management systems (Liesch et al., 2011; Askari et al., 2013, 2015; Ball et al., 2013; Giarola et al., 2013; Guimarães et al., 2013; Mueller et al., 2013; Munkholm et al., 2013; Askari and Holden, 2014; Cui et al., 2014; Pulido Moncada et al., 2014; Silva et al., 2014; Cui and Holden, 2015). Several studies identified close correlations between VESS Sq values and quantitative soil physical properties, such as soil bulk density, total porosity, air permeability, penetration resistance, aggregate tensile strength, mean weight diameter, saturated hydraulic conductivity, and least limiting water range (Mueller et al., 2009; Guimarães et al., 2011; Liesch et al., 2011; Garbout et al., 2013; Guimarães et al., 2013; Abdollahi and Munkholm, 2014). Guimarães et al. (2013) showed

Table 1. Average corn yield and stover harvested from 2008 through 2014 for corn stover harvest levels and tillage systems before the visual evaluation of soil structure (VESS) structural quality (Sq) score measurements.

\begin{tabular}{|c|c|c|c|c|}
\hline \multirow[b]{2}{*}{ Removal } & \multicolumn{2}{|c|}{ Chisel plow } & \multicolumn{2}{|c|}{ No-tillage } \\
\hline & Grain yield & Stover harvested & Grain yield & Stover harvested \\
\hline$\%$ & - & $M g$ & & \\
\hline 0 & 8.53 & 0 & 8.35 & 0 \\
\hline 50 & 9.79 & 3.74 & 9.22 & 3.34 \\
\hline 90 & 9.68 & 5.58 & 9.63 & 5.63 \\
\hline
\end{tabular}

that VESS (a simple indicator) and the least limiting water range (a complex indicator) often converge to identify highly restrictive soil physical conditions to plant growth when $\mathrm{Sq}$ is $>3.5$, suggesting that VESS encompasses complex physical functions (e.g., water availability, aeration, and rootability) related to the structural and physical quality of soils.

Currently, experimental data using VESS to evaluate impacts of corn stover harvest on soil structural quality are unavailable. Therefore, our objective was to determine if this semiquantitative, on-farm assessment approach would effectively evaluate soil structural quality after several years with different levels of corn stover harvest under two tillage systems in a long-term continuous corn experiment in Iowa.

\section{MATERIAL AND METHODS}

This study was performed on a site that was being used for a corn stover harvest experiment established in 2008 at the Iowa State University Agricultural Engineering/Agronomy (AEA) Research farm near Ames, IA ( $42.018^{\circ} \mathrm{N}$ lat; $-93.764^{\circ} \mathrm{W}$ long). Three soil series (Canisteo [poorly and very poorly drained fineloamy, mixed, superactive, calcareous, mesic Typic Endoaquoll], Clarion [well-drained fine-loamy, mixed, superactive, mesic Typic Hapludoll], and Webster [poorly drained fine-loamy, mixed, superactive, mesic Typic Endoaquoll]) are located at the site. The dominant textures are loam to clay loam. The study was initiated in 2008 on 12- by $90-\mathrm{m}$ plots in a randomized complete block design with four replications. The experiment consisted of corn continuously grown from 2008 to 2014 under two tillage systems: CP to a depth of $25 \mathrm{~cm}$ and NT. Due to adverse weather during the fall of 2014, the CP treatment was imposed to a depth of $25 \mathrm{~cm}$ in the spring of 2015 and followed by field cultivation to a depth of $10 \mathrm{~cm}$ just before planting corn. Corn was planted in rows spaced $75 \mathrm{~cm}$ apart at a population of 84,000 plants ha $^{-1}$. Three corn stover harvest treatments had been performed within each tillage system for the past $7 \mathrm{yr}$ : (i) no harvest with all corn stover remaining on the soil surface, (ii) moderate harvest with about $50 \%$ of corn stover left in the field, and (iii) high harvest, which removed approximately $90 \%$ of the corn stover. Due to consistently lower corn grain yields and therefore a lack of interest by stakeholders, the NT, no stover harvest treatment was discontinued in 2013 and replaced by a NT rotation that included 3 yr of alfalfa (Medicago sativa L.) followed by 2 yr of corn with high stover harvest. The average corn yield and stover harvested from 2008 through 2014 for corn stover harvest levels and tillage systems are presented in Table 1. Long-term average soil organic matter for samples collected from 2008 through 2014 before the VESS analysis are shown in Table 2.

Soil sampling for the VESS evaluation was performed in April 2015 when soil water content was near field capacity and before the CP treatment for 2015 was imposed. Samples were taken between crop rows, avoiding places with excessive machinery traffic. The VESS Sq measurements were done according to Ball et al. (2007) and Guimarães et al. (2011). Briefly, a straight spade was used to dig a mini-trench that was wider and 
deeper than the spade. An undisturbed block of soil that was $25 \mathrm{~cm}$ deep, $10 \mathrm{~cm}$ wide, and $20 \mathrm{~cm}$ long (i.e., a volume of 5000 $\mathrm{cm}^{3}$ ) was collected from each treatment and field replication, thus providing a total of 24 soil blocks that were each transferred to a separate plastic tray. The soil sample was gently manipulated and manually broken to expose soil aggregates, identify restrictive layers, and reveal whether roots were concentrated within inter- or intra-aggregate spaces. A visual interpretation chart or "key" proposed by Guimarães et al. (2011) was used as a guide for assigning the $\mathrm{Sq}$ scores for each layer identified as having a distinct soil structural quality. The method proposed by Guimarães et al. (2011) to reduce the size of aggregates to 1 to $2 \mathrm{~cm}$ and to evaluate their shape was useful for precisely assigning the scores. We measured the depth of the samples just after their removal and carefully identified layers having distinct soil structure differences after loosening the aggregates. Following the evaluation, pictures were taken and subsequently used to confirm the score assigned in the field. Since distinct layers were identified and a score was assigned for each layer identified according to the standard chart description, an overall weighted score for each soil sample was calculated. Giarola et al. (2010) and Guimarães et al. (2013) stressed the importance of evaluating soil layers individually rather than giving only a weighted average score because doing so can improve the choice of management practices adopted to preserve or improve overall structural soil quality. Thus, one additional strategy of scoring was also used: a weighted average of the $S q$ score was taken for the top $(0-5 \mathrm{~cm})$ and bottom $(5-20 \mathrm{~cm})$ soil layers at each sample using the depth and $\mathrm{Sq}$ scores of the naturally formed soil layers identified at the field. The interpretation of VESS was conducted according Ball et al. (2007), considering a Sq of 3 as a provisional threshold for the soil structural quality.

Statistical analyses were performed using the PROC ANOVA procedure in SAS version 9.3 (SAS Institute, 2011). Normality of the data was tested and confirmed using the Shapiro-Wilk test. The VESS data met the ANOVA assumptions, and no transformations were required. We found no significant block effects, so the statistical analyses were performed considering plots as samples in a completely randomized design. A two-way analysis of variance was performed, and when significant $(p<0.05)$, mean values were compared using Tukey's test $(p<0.05)$.

\section{RESULTS AND DISCUSSION}

Soil blocks from the CT and NT plots with the high corn stover harvest were more difficult to extract, and most of them had well-defined horizontal layers, large angular and subangular shaped aggregates, and were difficult to break, which are all signs of soil compaction and poor structure (Fig. 1). Visible porosity, considered a key feature when applying VESS (Guimarães et al., 2011), was more evident under no-harvest and moderate stover harvest, especially with NT plus alfalfa, which showed more abundant and continuous macropores that were vertically oriented and reached the bottom of the samples. Munkholm et
Table 2. Average soil organic matter $\left(\mathrm{g} \mathrm{kg}^{-1}\right)$ for samples from the 0- to 5- and 5- to $15-\mathrm{cm}$ soil layers collected from 2008 through 2014 under tillage systems and corn stover harvest levels in lowa.

\begin{tabular}{cccccc} 
& \multicolumn{2}{c}{ Chisel plow } & & \multicolumn{2}{c}{ No-tillage } \\
\cline { 2 - 3 } \cline { 5 - 6 } Removal (\%) & $\mathbf{0}$ to $\mathbf{5} \mathbf{~ c m}$ & $\mathbf{5}$ to $\mathbf{1 5} \mathbf{~ c m}$ & & $\mathbf{0}$ to $\mathbf{5} \mathbf{~ c m}$ & $\mathbf{5}$ to $\mathbf{1 5} \mathbf{~ c m}$ \\
\hline 0 & 32 & 32 & & 38 & 35 \\
50 & 37 & 36 & & 32 & 31 \\
90 & 33 & 33 & & 37 & 34 \\
\hline
\end{tabular}

al. (2013), who concluded that better soil structural quality is related to higher macroporosity, supported these results.

The VESS assessment took about $20 \mathrm{~min}$ for each sample, including the time for digging the mini-trench and assigning the scores. This was similar to the time reported by Cui et al. (2014) for Irish soils. The photos taken of the VESS evaluation were useful for reviewing and confirming the scores assigned. We also highlight the importance of breaking larger aggregates into 1- to 2 -cm fragments to improve the assessments, particularly for $\mathrm{Sq}$ scores between 3 and 4 . The sampling depth ranged from 23 to $27 \mathrm{~cm}$, with most of samples being $25 \mathrm{~cm}$ in length as planned. For most of samples (23 out of 24), two distinct layers (top and bottom) were identified. The other sample had three layers. To provide comparable data for statistical analysis, adjacent, similar layers for this one sample were amalgamated for statistical analysis as recommended by Giarola et al. (2013). A VESS Sq of 5, indicating very poor soil structural quality, was not observed. The top layer had average values of $11.25,13.50$, and $2.25 \mathrm{~cm}$ for $\mathrm{CP}$ and $11.00,9.50$, and $5.80 \mathrm{~cm}$ for NT under no-harvest, moderate corn stover harvest, and high corn stover harvest levels, respectively. The bottom layer averaged 13.50, 11.00, and $22.75 \mathrm{~cm}$ for CP while NT had average values of $14.50,15.00$, and $19.25 \mathrm{~cm}$ under no-harvest, moderate corn stover harvest, and high corn stover harvest levels, respectively. The highest $(\mathrm{Sq}$ $=3.84)$ and lowest $(\mathrm{Sq}=1.70)$ overall scores had coefficients of variation of about $23 \%$. However, within individual layers, $\mathrm{Sq}$ values ranging from 1 to 4 were recorded, indicating that soil structural quality among the various treatments varied from good to poor, respectively. Within this Sq range, breaking soil aggregates requires a gradual effort for crushing them between the fingers, with one hand and with both hands, as reported by Guimarães et al. (2011).

A significant interaction between corn stover harvest level and tillage system $(F=6.56 ; p<0.05)$ was noted for the overall average VESS Sq, indicating that soil structure under the various corn stover harvest levels had distinct responses for the tillage systems studied. The overall average VESS Sq values are shown in Fig. 2.

The average Sq scores varied from 1.97 to 3.71 , with the lowest and highest $\mathrm{Sq}$ scores being found for NT plus alfalfa and CP under high stover harvest, respectively. There were no significant differences in $\mathrm{Sq}$ values between tillage systems since corn stover harvest did not exceed the moderate level (about 50\%). However, under high corn stover harvest levels, NT Sq was statistically lower than CP Sq (Fig. 2). These results show that complete stover harvest had the most detrimental effects on soil structural quality assessed by the VESS method. They are 


\section{Corn stover harvest level}

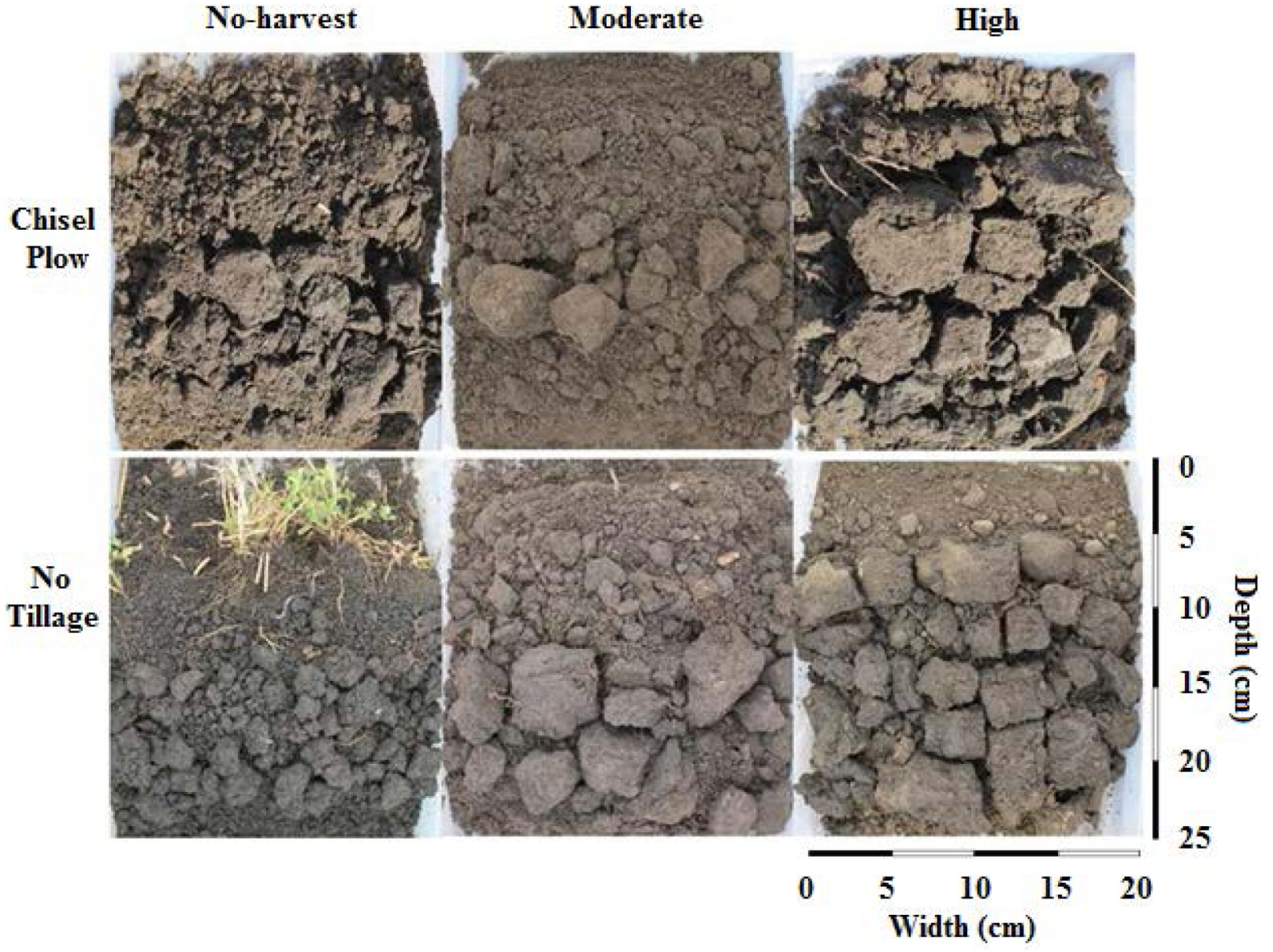

Fig. 1. Appearance of soil samples after visual evaluation of soil structure (VESS) structural quality (Sq) assessments for chisel plow and no-tillage treatments under three corn stover harvest levels.

also consistent with results reported by Blanco-Canqui and Lal (2008). High corn stover harvest level severely degraded the soil structure under $\mathrm{CP}$, resulting in very large clods that composed a larger proportion of the sample (Fig. 1) and contributed to an in-

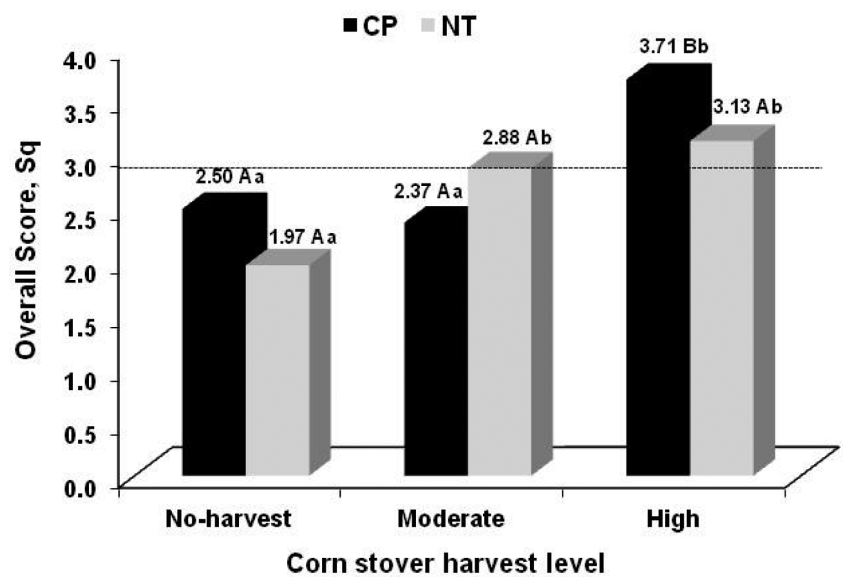

Fig. 2. Overall visual evaluation of soil structure (VESS) structural quality (Sq) scores at corn stover harvest levels under no-tillage (NT) and chisel plow (CP). The dashed line indicates the critical limit of $\mathrm{Sq}$ according to Ball et al. (2007). Means followed by the same capital letter within each stover harvest level and lowercase letter within each tillage system are not significantly different according to Tukey's test at the $p<0.05$ level. crease in the VESS Sq score. The results obtained by BlancoCanqui and Lal (2008) and Wegner et al. (2015) suggest that complete corn stover harvest reduces the input of hydrophobic organic compounds, which reduces water repellency of the aggregates, making them more prone to slaking and dispersion, and thus favoring the occurrence of larger and harder aggregates. Under moderate corn stover harvest, despite there being no statistical difference between $\mathrm{CP}$ and NT, the tendency was for NT Sq to be greater than CP Sq. Better structural quality within tilled soils than non-tilled soils was also reported by Munkholm et al. (2013) and Abdollahi and Munkholm (2014). Therefore, the overall Sq of 2.88 under NT with moderate stover harvest indicates that soil structural quality is getting firm, but it is still suitable for crop production. The lowest Sq values were found under NT where alfalfa had been introduced for $1 \mathrm{yr}$, confirming that it could improve soil structural quality as previously demonstrated by Imhoff et al. (2009). Recently, Munkholm et al. (2013) and Abdollahi et al. (2015) also showed that more diversified cropping systems improved soil structural quality (i.e., resulted in lower VESS Sq scores).

Increasing stover harvest levels from no-harvest to high indicate that soil structure is being distinctly modified under both $\mathrm{CP}$ and NT (Fig. 1 and 2). In NT, there was a gradual increase 
of VESS Sq from the no-harvest to the high harvest level, although $S q$ was statistically similar between moderate and high levels of stover harvest. For CP under high corn stover harvest, an abrupt increase in $\mathrm{Sq}$ that was significantly higher than that under no-harvest and moderate corn stover harvest was verified (Fig. 2). These results suggest that even with moderate harvest, soil structural quality under NT could be more dependent on other improved management practices, such as cover crops. Under NT, soil structure is strongly dependent on C inputs and biological activity, which are negatively affected by corn stover harvest (Moebius-Clune et al., 2008; Hammerbeck et al., 2012; Osborne et al., 2014; Wegner et al., 2015). On the other hand, C inputs by corn stover incorporation under no-harvest and moderate harvest in $\mathrm{CP}$ could protect soil aggregates against their coalescence and recompaction. Uncoalesced aggregates are stable, soft, loose, and crumbly, while coalesced aggregates are hard and break up with brittle fracture into fragments rather than into peds. These aggregate responses were observed from no-harvest to complete stover harvest in both NT and CP when breaking up and reducing aggregates size to assign the $\mathrm{Sq}$ score.

Under NT with moderate stover harvest, Sq values approach the threshold value and need to be monitored to prevent management decisions that unintentionally result in structural degradation. According to Ball et al. (2007), overall soil structural quality at this site is classified as good in both NT and CP under no- and moderate corn stover harvest, while plots with complete harvest are classified as compact. Using Ball's recommendation, $\mathrm{Sq}$ values of $>3$ associated with high stover harvest indicated that improved management practices, such as cover crops, crop rotation, or even a residue harvest rotation plan, are necessary to avoid severe structural degradation for sustained crop production. Liesch et al. (2011) verified that soil Sq was improved in a rye (Secale cereale L.) and corn silage doublecropping system compared with continuous corn silage. Our results for CP and NT treatments, which had Sq values of $<3$ for both no-harvest and moderate harvest histories, indicated that both tillage systems were sustaining good soil structural quality. However, NT may be recommended as a more sustainable management practice under moderate corn stover harvest since it provides nonlimiting soil structural quality (VESS Sq $<3$ ) and protection against erosion. In contrast, soil structural quality was not sustained under high levels of corn stover harvest, suggesting that a judicious corn stover management must be done to preserve the structural and physical quality of these soils.

An important feature of the VESS methodology is that it helps users to identify layers with different soil structural conditions by providing more detailed information based on the best and worst VESS Sq scores (Giarola et al., 2010; Guimarães et al., 2011). The soil surface (usually the first $5 \mathrm{~cm}$ ) is considered a critical management zone for many processes related to soil structure, such as water infiltration, seedling emergence, and controlling soil erosion and runoff of chemicals to surface waters. Therefore, we calculated a weighted average $\mathrm{Sq}$ for the 0- to 5(top layer) and 5- to 20-cm (bottom layer) depth increments to get more detailed information regarding the treatment impacts on topsoil structural quality (Fig. 3). Similar to the overall Sq values, we found a statistically significant interaction between corn stover harvest levels and tillage systems for Sq scores within both the top layer $(F=5.52 ; p<0.05)$ and bottom layer $(F=4.77$; $p<0.05)$. Our results showed that soil structural quality measured by VESS Sq decreased with depth regardless of corn stover harvest and soil tillage system. Better soil structural quality was identified on plots with NT plus alfalfa, in which biologically active roots and more earthworms (not measured) than the other treatments were observed.

The Sq scores within both the top and bottom layers resembled the behavior described for the overall Sq score (Fig. 2). Under high stover harvest, NT had a Sq of $<3$ in the top layer and a Sq of $>3$ in the bottom layer for CP and NT, respectively. The Sq of $>3$ in the CP top layer suggests that risks of soil erosion are likely increased due to the absence of soil cover as shown by Kenney et al. (2015). The Sq scores in CP and NT were influenced by corn stover harvest at both layers. The values showed the gradual increase of Sq in NT, but an abrupt increase of Sq was verified under the $\mathrm{CP}$ high stover harvest. Regardless of the corn stover harvest level, NT had a very good soil structural quality within the $5-\mathrm{cm}$ surface layer $(\mathrm{Sq}<2)$, suggesting that NT confers structural resistance and resilience to the soil. The significant differences in the NT top layer Sq scores for no-harvest and complete stover harvest have no
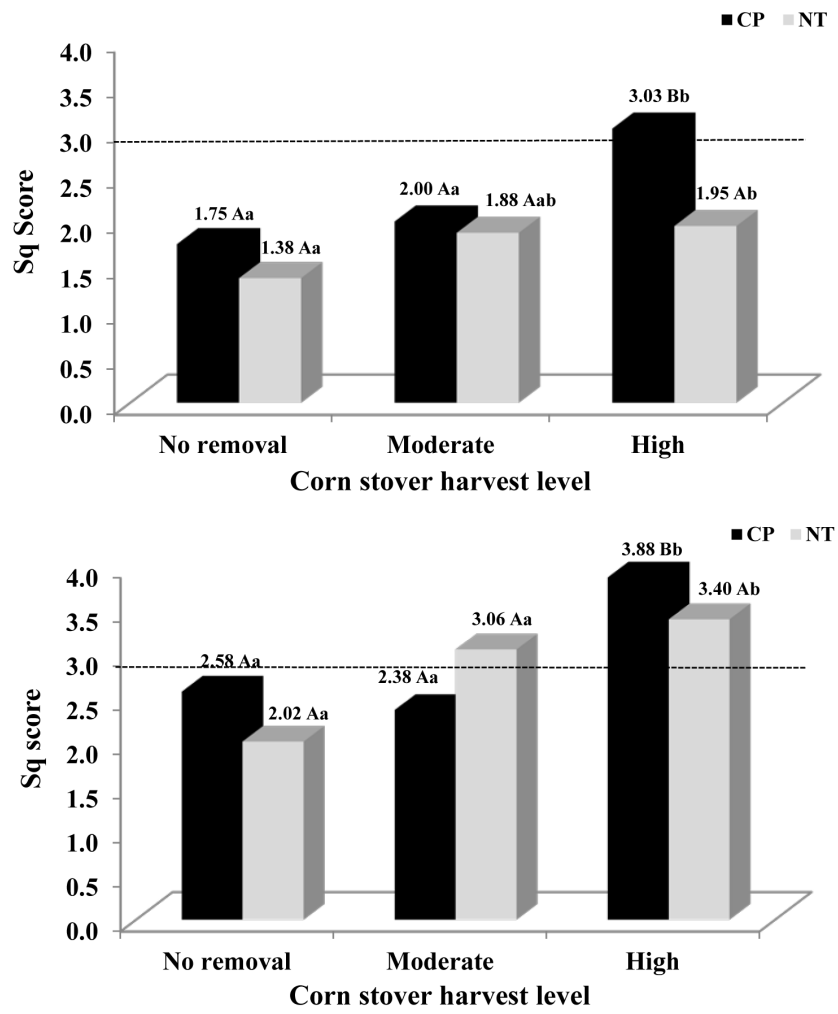

Fig. 3. Weighted average visual evaluation of soil structure (VESS) structural quality (Sq) scores for the top layer (0 to $5 \mathrm{~cm}$, Top) and bottom layer ( 5 to $20 \mathrm{~cm}$, Bottom). The dashed line indicates the critical limit of Sq according to Ball et al. (2007). Means followed by the same capital letter within each stover harvest level and lowercase letter within each tillage system are not significantly different according to Tukey's test at the $\boldsymbol{p}<0.05$ level. CP, chisel plow; NT, no-tillage. 
important physical meaning since a $\mathrm{Sq}$ of $<2$ indicates good soil structural quality (Askari et al., 2013).

Within the bottom layer (5- to 20-cm depth), soil structural quality may be classified as good for $\mathrm{CP}$ under no-harvest $(\mathrm{Sq}$ $=2.58)$ and moderate harvest $(\mathrm{Sq}=2.38)$ and for NT plus alfalfa $(\mathrm{Sq}=2.02)$ to firm (i.e., becoming compacted) for NT with moderate stover harvest, in which the $\mathrm{Sq}$ was slightly higher than $3(\mathrm{Sq}=3.06)$. These values are consistent with those reported by Garbout et al. (2013). For CP and complete stover harvest, a Sq of $>3$ in both layers suggests that the soil physical environment is being degraded due to soil compaction. However, under NT, the presence of continuous macropores may positively affect crucial soil functions related to water flow, aeration, and root growth. Macropores can also alleviate higher soil mechanical impedance for root growth in NT soils (Ehlers et al., 1983) and improve soil aeration under wet conditions. Furthermore, with NT and moderate stover harvest, our results suggest that adopting even better soil management practices, such as cover crops, could further improve and preserve soil structural quality as suggested by Karlen et al. (2011a). This recommendation is highlighted by the new rotation that utilizes alfalfa to improve soil structure quality within the whole profile. Combined with NT, the reduced machinery traffic with alfalfa during spring and fall when soils in this area are often wet may have contributed to better soil structural quality. A more diverse cropping system with higher yield levels is essential for achieving sustained soil structural quality.

Visual evaluation of soil structure (VESS) Sq values of $>3$ (e.g., $\mathrm{NT}=3.40 ; \mathrm{CP}=3.88$ ) indicate that soil structure was degraded in both tillage systems with high stover harvest. Despite better structural conditions within the top layer under NT, we consider that complete corn stover harvest could be an unsustainable management practice for both NT and CP systems. Although axel load and wheel traffic intensity have not been documented for this experimental site, we recognize that corn stover harvest operations impose additional stress and compactive forces on soils within the field. Therefore, a judicious, sitespecific stover management plan should be developed to prevent excessive compaction and structural quality degradation. Results achieved by Braida et al. (2006) showed that increasing corn stover on the soil surface dissipated up to $30 \%$ of the compressive energy applied by agricultural machinery, protecting the soil under NT against compaction. However, under the larger and heavier agricultural machines used for extensive crop production, the ability of the residue to withstand the heavy wheel loads applied to the soil may be limited. Subsoil compaction may also be a potentially negative impact of excessive stover harvest under CP as suggested by an average Sq value of 3.88 for the 5- to 20-cm layer. Our assessment did not examine subsoil conditions, although a visual methodology for evaluation of subsoil compaction was recently proposed by Ball et al. (2015) and may be useful for assessing the impacts of tillage systems and corn stover harvest for biofuel production.

Overall, the VESS method allowed for a simple, rapid, lowcost, and integrative measurement of soil structural quality that can be useful for monitoring the impacts of corn stover harvest. Our results showed that the VESS Sq score was sensitive enough to capture the spatial variability of soil structure induced by tillage systems and stover harvest beyond top layers. According to Karlen et al. (2011b), organic C should be monitored to quantify stover harvest effects on soil quality. In addition to Karlen's recommendation, we suggest that taking VESS measures after corn harvest season could be useful for monitoring soil structural quality under stover harvest practices, providing technical support for farmers and advisers in making decisions about management practices to sustain soil structural quality for soil and crop productivity. The VESS approach was sensitive for detecting effects of corn stover harvest and tillage practice on soil structural quality and should be further evaluated as an integrative soil quality/health indicator.

\section{CONCLUSIONS}

The results obtained in this study suggest that VESS was sensitive and suitable for detecting differences in soil structural quality under corn stover harvest levels and tillage systems. Soil structural quality was not significantly affected by tillage effects since corn stover harvesting is done at a moderate level of about $50 \%$. The Sq values of $<3$ or around 3 for no harvest and moderate harvest indicate that soil structural quality is favorable for agricultural purposes in both CP and NT. However, regardless of the soil tillage system, the complete corn stover harvest resulted in degradation in soil structural quality (VESS Sq > 3 ), demanding improved management practices to recover soil structural quality for crop production. Our results suggest that incorporating alfalfa into more diversified crop rotations could improve overall soil structural quality. The VESS method allowed for a simple, rapid, low-cost, and integrative measurement of soil structural quality that might be useful for monitoring the impacts of corn stover harvest, providing support for farmers and advisers in making decisions about management practices to sustain soil structural quality for soil and crop productivity.

\section{ACKNOWLEDGMENTS}

C.A. Tormena thanks the National Council for Scientific and Technological Development (CNPq), Brazil for the scholarship (process 203376/2014-5) granted as a visiting scientist at the National Laboratory for Agriculture and the Environment, USDA/ARS, Ames, IA. M.R. Cherubin thanks the São Paulo Research Foundation (FAPESP) for research grants (processes 2013/17581-6 and 2014/16612-8).

\section{REFERENCES}

Abdollahi, L., E.M. Hansen, R.J. Rickson, and L.J. Munkholm. 2015. Overall assessment of soil quality on humid sandy loams: Effects of location, rotation and tillage. Soil Tillage Res. 145:29-36. doi:10.1016/j.still.2014.08.009

Abdollahi, L., and L.J. Munkholm. 2014. Tillage system and cover crop effects on soil quality: I. Chemical, mechanical, and biological properties. Soil Sci. Soc. Am. J. 78:262-270. doi:10.2136/sssaj2013.07.0301

Askari, M.S., J. Cui, and N.M. Holden. 2013. The visual evaluation of soil structure under arable management. Soil Tillage Res. 134:1-10. doi: 10.1016/j.still.2013.06.004

Askari, M.S., J. Cui, S.M. O’Rourke, and N.M. Holden. 2015. Evaluation of soil structural quality using VIS-NIR spectra. Soil Tillage Res. 146:108-117. doi:10.1016/j.still.2014.03.006

Askari, M.S., and N.M. Holden. 2014. Indices for quantitative evaluation of 
soil quality under grassland management. Geoderma 230-231:131-142. doi:10.1016/j.geoderma.2014.04.019

Ball, B.C., T. Batey, and L.J. Munkholm. 2007. Field assessment of soil structural quality: A development of the Peerlkamp test. Soil Use Manage. 23:329337. doi:10.1111/j.1475-2743.2007.00102.x

Ball, B.C., T. Batey, L.J. Munkholm, R.M.L. Guimarães, H. Boizard, D.C. McKenzie, J. Peigné, C.A. Tormena, and P. Hargreaves. 2015. The numeric visual evaluation of subsoil structure (SubVESS) under agricultural production. Soil Tillage Res. 148:85-96. doi:10.1016/j.still.2014.12.005

Ball, B.C., L.J. Munkholm, and T. Batey. 2013. Applications of visual soil evaluation. Soil Tillage Res. 127:1-2. doi:10.1016/j.still.2012.12.002

Blanco-Canqui, H., R.B. Ferguson, V.L. Jin, M.R. Schmer, B.J. Wienhold, and J. Tatarko. 2014. Can cover crop and manure maintain soil properties after stover removal from irrigated no-till corn? Soil Sci. Soc. Am. J. 78:13681377. doi:10.2136/sssaj2013.12.0550

Blanco-Canqui, H., and R. Lal. 2007. Soil and crop response to harvesting corn residues for biofuel production. Geoderma 141:355-362. doi:10.1016/j. geoderma.2007.06.012

Blanco-Canqui, H., and R. Lal. 2008. Corn stover removal impacts on microscale soil physical properties. Geoderma 145:335-346. doi:10.1016/j. geoderma.2008.03.016

Blanco-Canqui, H., and R. Lal. 2009a. Crop residue removal impacts on soil productivity and environmental quality. Crit. Rev. Plant Sci. 28:139-163. doi:10.1080/07352680902776507

Blanco-Canqui, H., and R. Lal. 2009b. Corn stover removal for expanded uses reduces soil fertility and structural stability. Soil Sci. Soc. Am. J. 73:418426. doi:10.2136/sssaj2008.0141

Blanco-Canqui, H., R. Lal, W.W. Post, R.C. Izaurralde, and L.B. Owens. 2006. Corn stover impacts on near-surface soil properties of no-till corn in Ohio. Soil Sci. Soc. Am. J. 70:266-278. doi:10.2136/sssaj2005.0137

Blanco-Canqui, H., R. Lal, W.W. Post, R.C. Izaurralde, and M.J. Shipitalo. 2007. Soil hydraulic properties influenced by corn stover removal from no-till corn in Ohio. Soil Tillage Res. 92:144-155. doi:10.1016/j.still.2006.02.002

Braida, J.A., J.M. Reichert, M. da Veiga, and D.J. Reinert. 2006. Mulch and soil organic carbon content and their relationship with the maximum soil density obtained in the proctor test. (In Portuguese, with English abstract.) Rev. Bras. Ci. Solo 30:605-614.

Cui, J., M.S. Askari, and N.M. Holden. 2014. Visual evaluation of soil structure under grassland management. Soil Use Manage. 30:129-138. doi:10.1111/sum.12100

Cui, J., and N.M. Holden. 2015. The relationship between soil microbial activity and microbial biomass, soil structure and grassland management. Soil Tillage Res. 146:32-38. doi:10.1016/j.still.2014.07.005

Ehlers, W.W., F. Kopke, F. Hesse, and W. Bohm. 1983. Penetration resistance and root growth of oats in tilled and untilled loess soil. Soil Tillage Res. 3:261-275. doi:10.1016/0167-1987(83)90027-2

Garbout, A., L.J. Munkholm, and S.B. Hansen. 2013. Tillage effects on topsoil structural quality assessed using X-ray $\mathrm{CT}$, soil cores and visual soil evaluation. Soil Tillage Res. 128:104-109.doi:10.1016/j.still.2012.11.003

Giarola, N.F.B., A.P. Silva, C.A. Tormena, B.C. Ball, and J.A. Rosa. 2010. Visual soil structure quality assessment on Oxisols under no-tillage system. Sci. Agric. (Piracicaba, Braz.) 67:479-482. doi:10.1590/S0103-90162010000400016

Giarola, N.F.B., A.P. Silva, C.A. Tormena, R.M.L. Guimarães, and B.C. Ball. 2013. On the visual evaluation of soil structure: The Brazilian experience in Oxisols under no-tillage. Soil Tillage Res. 127:60-64. doi:10.1016/j.still.2012.03.004

Guimarães, R.M.L., B.C. Ball, and C.A. Tormena. 2011. Improvements in the visual evaluation of soil structure. Soil Use Manage. 27:395-403.

Guimarães, R.M.L., B.C. Ball, C.A. Tormena, N.F.B. Giarola, and A.P. Silva. 2013. Relating visual evaluation of soil structure to other physical properties in soils of contrasting texture and management. Soil Tillage Res. 127:92-99. doi:10.1016/j.still.2012.01.020

Hammerbeck, A.L., S.J. Stetson, S.L. Osborne, T.E. Schumacher, and J.L. Pikul. 2012. Corn residue removal impact on soil aggregates in a no-till corn/soybean rotation. Soil Sci. Soc. Am. J. 76:1390-1398. doi:10.2136/sssaj2011.0421

Imhoff, S., H. Imvinkelried, C.A. Tormena, and A.P. Silva. 2009. Calificacion visual a campo de la calida estructural de Argiudoles bajo diferentes sistemas de manejo. (In Spanish, with English abstract.) Cienc. Suelo 27:247-253.

Jin, V.L., M.R. Schmer, B.J. Wienhold, C.E. Stewart, G.E. Varvel, A.J. Sindelar, R.F. Follet, R.B. Mitchell, and K.P. Vogel. 2015. Twelve years of stover removal increases soil erosion potential without impacting yield. Soil Sci. Soc. Am. J. 79:1169-1178. doi:10.2136/sssaj2015.02.0053

Johnson, J.M.F., D. Reicosky, R.R. Allmaras, D. Archer, and W. Wilhelm. 2006.
A matter of balance: Conservation and renewable energy. J. Soil Water Conserv. 61:120A-125A.

Karlen, D.L., S.J. Birell, and J.R. Hess. 2011a. A five-year assessment of corn stover harvest in central Iowa, USA. Soil Tillage Res. 115-116:47-55. doi:10.1016/j.still.2011.06.006

Karlen, D.L., S.J. Birrel, J.M.F. Johnson, S.L. Osborne, T.E. Schumacher, G.E. Varvel, R.B. Ferguson, J.M. Novak, Jr., J.M. Fredrick, J.A. Baker, P.R. Lamb, G.W. Adler, and E. Nafziger. 2014. Multilocation corn stover harvest effects on crop yields and nutrient removal. BioEnerg. Res. 7:528-539. doi:10.1007/s12155-014-9419-7

Karlen, D.L., G.E. Varvel, J.M.F. Johnson, J.M. Baker, S.L. Osborne, J.M. Novak, P.R. Adler, G.W. Roth, and S.J. Birrell. 2011b. Monitoring soil quality to assess the sustainability of harvesting corn stover. Agron. J. 103:288-295. doi:10.2134/agronj2010.0160s

Karlen, D.L., N.C. Wollenhaupt, D.C. Erbach, E.C. Berry, J.B. Swan, N.S. Eash, and J.L. Jordahl. 1994. Crop residue effects on soil quality following 10-years of no-till corn. Soil Tillage Res. 31:149-167. doi:10.1016/01671987(94)90077-9

Kenney, I., H. Blanco-Canqui, D.R. Presley, C.W. Rice, K. Janssen, and B. Olson. 2015. Soil and crop response to stover removal from rainfed and irrigated corn. GCB Bioenerg. 7:219-230. doi:10.1111/gcbb.12128

Laird, D.A., and C. Chang. 2013. Long-term impacts of residue harvesting on soil quality. Soil Tillage Res. 134:33-40. doi:10.1016/j.still.2013.07.001

Liesch, A.M., E.S. Krueger, and T.E. Ochsner. 2011. Soil structure and physical properties under rye-corn silage double-cropping systems. Soil Sci. Soc. Am. J. 75:1307-1314. doi:10.2136/sssaj2010.0292

Moebius-Clune, B.N., H.M. Van Ess, O.J. Idowu, R.R. Schindelbeck, D.J. Moebius-Clune, D.W. Wolfe, G.S. Abawi, J.E. Thies, B.K. Gugino, and R. Lucey. 2008. Long-term effects of harvesting maize stover and tillage on soil quality. Soil Sci. Soc. Am. J. 72:960-969. doi:10.2136/sssaj2007.0248

Mueller, L., B.D. Kay, C. Hu, Y. Li, U. Schindler, A. Behrendt, T.G. Shepherd, and B.C. Ball. 2009. Visual assessment of soil structure: Evaluation of methodologies on sites in Canada, China and Germany. Part I: Comparing visual methods and linking them with soil physical data and grain yield of cereals. Soil Tillage Res. 103:178-187. doi:10.1016/j.still.2008.12.015

Mueller, L., G. Shepherd, U. Schindler, B.C. Ball, L.J. Munkholm, V. Hennings, E. Smolentseva, O. Rukhovic, S. Lukin, and C. Hu. 2013. Evaluation of soil structure in the framework of an overall soil quality rating. Soil Tillage Res. 127:74-84. doi:10.1016/j.still.2012.03.002

Munkholm, L.J., R.J. Heck, and B. Deen. 2013. Long-term rotation and tillage effects on soil structure and crop yield. Soil Tillage Res. 127:85-91. doi:10.1016/j.still.2012.02.007

Osborne, S.L., J.M.F. Johnson, V.L. Jin, A.L. Hammerbeck, G.E. Varvel, and T.E. Schumacher. 2014. The impact of corn residue removal on soil aggregates and particulate organic matter. BioEnerg. Res. 7:559-567. doi:10.1007/ s12155-014-9413-0

Pulido Moncada, M., L.H. Penning, L.C. Timm, D. Gabriels, and W.M. Cornelis. 2014. Visual examinations and soil physical and hydraulic properties for assessing soil structural quality of soils with contrasting textures and landuses. Soil Tillage Res. 140:20-28. doi:10.1016/j.still.2014.02.009

SAS Institute. 2011. The SAS system for Windows. Release 9.3. SAS Inst., Cary, NC.

Silva, A.P., B.C. Ball, C.A. Tormena, N.F.B. Giarola, and R.M.L. Guimaraes. 2014. Soil structure and greenhouse gas production differences between row and interrow positions under no-tillage. Sci. Agric. (Piracicaba, Braz.) 71:157-162. doi:10.1590/S0103-90162014000200011

Six, J., E.T. Elliot, and K. Paustian. 2000. Soil macroaggregate turnover and microaggregate formation: A mechanism for $\mathrm{C}$ sequestration under notillage agriculture. Soil Biol. Biochem. 32:2099-2103. doi:10.1016/ $\underline{\text { S0038-0717(00)00179-6 }}$

Villamil, M.B., J. Little, and E.D. Nafziger. 2015. Corn residue, tillage, and nitrogen rate effects on soil properties. Soil Tillage Res. 151:61-66. doi:10.1016/j.still.2015.03.005

Villamil, M.B., and E.D. Nafziger. 2015. Corn residue, tillage, and nitrogen rate effects on soil carbon and nutrient stocks in Illinois. Geoderma 253254:61-66. doi:10.1016/j.geoderma.2015.04.002

Wegner, B.R., S. Kumar, S.L. Osborne, T.E. Schumacher, I.I. Vahyala, and A. Eynard. 2015. Soil response to corn residue removal and cover crops in eastern South Dakota. Soil Sci. Soc. Am. J. 79:1179-1187. doi:10.2136/sssaj2014.10.0399

Wilhelm, W.W., J.M.F. Johnson, J.L. Hatfield, W.B. Voorhees, and D.R. Linden. 2004. Crop and soil productivity response to corn stover removal: A literature review. Agron. J. 96:1-17. doi:10.2134/agronj2004.0001 